\title{
Potential of Lactobacillus casei Shirota Strain as Probiotic toward MDA Levels and Histopathology of Aortic Tissues in Rat with High Cholesterol Diet
}

\author{
Kiswanti Surya Utami ${ }^{1, b)^{*}}$, Chanif Mahdi ${ }^{1}$, Aulanni'am Aulanni'am ${ }^{1,2, a)^{*}}$ \\ ${ }^{1}$ Chemistry Department, Faculty of Mathematics and Natural Sciences, Brawijaya University, \\ Indonesia \\ ${ }^{2}$ Faculty of Veterinary, Brawijaya University, Indonesia

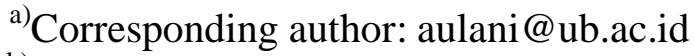 \\ b) anotherauthor: onetykeyko@gmail.com
}

\begin{abstract}
Hypercholesterolemia is a major risk factor of cardiovascular disease. Hypercholesterolemia is a condition that the cholesterol levels in the body exceed the normal limits. The main factor that causes high cholesterol levels in the body is a high-cholesterol diet. The provision of highcholesterol diet may improve cholesterol levels, especially LDL cholesterol. This condition leads to LDL oxidation, furthermore generation of free radicals or ROS that causing lipid peroxidation. Products of lipid peroxidation by ROS compound is an MDA compound. Countermeasures against ROS required antioxidant compounds. Probiotics that contain lactic acid bacteria can increase antioxidant. Probiotic of Lactobacillus casei Shirota strain contained of lactic acid bacteria that can increase the antioxidant content and decrease cholesterol levels. The aim of this study was to determine the probiotic of Lactobacillus casei Shirota strain potential to MDA levels of rats blood serum and histopathology of rats aortic tissue that fed with high-cholesterol diet. This study used male white rats (Rattus norvegicus) Wistar strain were divided into negative and positive group and therapy groups doses of Lactobacillus casei Shirota strain is: $0.5,1$ and $1.5 \mathrm{~mL} / \mathrm{rat} / \mathrm{day}$, that each group contained 5 rats.. The positive control group and therapy group administrated high-cholesterol diet for 21 days. The results showed that probiotic of Lactobacillus casei Shirota strain decreased the MDA levels of blood serum up to 60.15\% at dose of $1.5 \mathrm{~mL} / \mathrm{rat} / \mathrm{day}$ and can improve the histopathology of aortic tissue on high-cholesterol diet rats. This result demonstrated that Lactobacillus casei Shirota strain probiotic had potentially as treatment of hypercholesterolemia.
\end{abstract}

Keywords: cholesterol, malondialdehyde (MDA), Lactobacillus casei Shirota strain

\section{INTRODUCTION}

The high cholesterol levels in the body or hypercholesterolemia is the major risk factor of atherosclerosis. Death caused of atherosclerosis in Indonesia reach almost $50 \%{ }^{1}$. Atherosclerosis is a disease that caused by blockage of aortic due to LDL cholesterol accumulation. The high cholesterol levels in the body caused by high-cholesterol diet. Cholesterol that synthesized by liver will be inhibited when high-cholesterol diet is over consumption ${ }^{2}$. 
The high cholesterol diet consumption increasing LDL cholesterol levels, furthermore lead of LDL cholesterol oxidation and generation of free radical or ROS (Reactive Oxygen Species) in the body. The exceed ROS compound caused oxidative stress ${ }^{3}$. Oxidative stress condition caused lipid peroxidation in the body that generated of MDA (malondialdehyde) compound. MDA profile in blood serum is an indicator of cellular damage due to ROS. The higher levels of ROS make levels of MDA became higher, too ${ }^{4}$.

The prevention against ROS required antioxidant compounds. Antioxidant can be improved by probiotics that contain lactic acid bacteria. Probiotic of Lactobacillus casei Shirota strain contained of lactic acid bacteria that can improve antioxidant content. Fermented milk of lactic acid have high antioxidant activity, otherwise probiotic also have hypocholesterolemic effect. The fermented milk of Lactobacillus casei Shirota strain can decrease level of cholesterol total equal to $25.7 \mathrm{mg} / \mathrm{dL}$ at dose of $2.5 \mathrm{~mL} / \mathrm{rat} / \mathrm{day}^{5}$. Yogurt contained of Lactobacillus bulgaricus that given in dyslipidemia rats can decrease triglyceride levels but cannot decrease cholesterol total levels ${ }^{6}$. Each probiotic will gave different results for decreasing cholesterol level. The aim of this study was to determine the potency of Lactobacillus casei Shirota strain toward MDA levels and histopathology of aortic that fed with highcholesterol diet.

\section{MATERIALS AND METHODS}

\section{Chemicals and Instruments}

The chemicals used in this study were probiotic of Lactobacillus casei Shirota strain, cholic acid, quail egg yolk, pure cholesterol, used oil, hydrochloric acid, TCA (Trichloroacetic acid) (MP Biomedical), MDA standard (Sigma-Aldrich), 0,9\% sodium chloride, hematoxylin-eosin (HE) stains, Na-thio, paraformaldehyde, phosphate buffer saline, and aluminum foil.

The equipment used in this research were glass tools, micro-pipette, glass object, spectrophotometer (Thermoscientific Genesys 20), microscope (Olympus BX51), Easy Touch GCU for check cholesterol levels, scale, water bath, micro tube, syringe $3 \mathrm{~mL}$ (Terumo), cuvet, and vacutainer tube Non-EDTA.

\section{Preparation of Experimental Animals}

Male white rats (Rattus norvegicus) Wistar strain was divide into 5 groups. The control group there are 2 groups that negative control (NC) and positive control (PC), while the other three groups were treated by probiotic of Lactobacillus casei Shirota strain with dose of 0.5, 1 and $1.5 \mathrm{~mL} / \mathrm{rat} / \mathrm{day}$. The positive control group administrated high-cholesterol diet for twenty-one days. Therapy groups were orally given through 14 days. The use of rats was approved by Ethic Committee No. KEP-554UB. High-cholesterol diet consists of cholic acid, quail egg yolk, purecholesterol and oil. The blood serum of rats was collected for analysis of MDA levels and aortic tissue for analysis of histopathology used hematoxylin-eosin.

\section{Measurement MDA Levels of Blood Serum}

The MDA levels were determining use Tiobarbituric acid (TBA). The blood serum of rats was taken about $100 \mu \mathrm{L}$, than were added with $550 \mu \mathrm{L}$ of distilled water. Subsequently, the blood serum 
was added with $100 \mu \mathrm{L}$ of TCA $10 \%, 250 \mu \mathrm{L}$ of $1 \mathrm{~N} \mathrm{HCl}$ and $100 \mu \mathrm{L}$ of Na-thio, then mixed and homogenized using vortex, then it was centrifuged at $500 \mathrm{rpm}$ for $10 \mathrm{~min}$. Afterwards, the supernatant were collected and incubated in waterbath at temperature $100{ }^{\circ} \mathrm{C}$ for $30 \mathrm{~min}$. Sample were measured at $\lambda \max$ of $530 \mathrm{~nm}$.

\section{Histopathology Examination of Aortic}

The histopathology examination of aortic using hematoxylin-eosin stains. Aortic histopathology of rats was observed by microscope with magnification of 400x.

\section{RESULTS AND DISCUSSIONS}

The result showed that probiotic of Lactobacillus casei Shirota strain can decrease MDA levels. The results of statistical analysis were determined using One Way ANOVA and exhibited that probiotic therapy with Lactobacillus casei Shirota strain with variation dose of 0.5 , 1.0, and 1.5 $\mathrm{mL} / \mathrm{rat} /$ day can decrease the MDA levels significantly $(\mathrm{p}<0.01)$.

The average MDA levels of positive control increased cholesterol up to $205.62 \%$ (Tab 1). This result indicates that administration of high-cholesterol diet can increase the total cholesterol levels and trigger the forming of free radical. The deposit of excess LDL cholesterol in blood vessels will be oxidized, and make trigger the increasing production of free radical compound or ROS.

TABLE 1. The MDA levels after therapy administrated probiotic of Lactobacillus casei Shirota strain

\begin{tabular}{lccc}
\hline Group & $\begin{array}{c}\text { The Average of } \\
\text { MDA Level in } \\
\text { Blood }(\boldsymbol{\mu g} / \mathbf{m L})\end{array}$ & $\begin{array}{c}\text { Increasing of MDA } \\
\text { Levels in Blood } \\
\text { towards Negative } \\
\text { Control } \\
(\boldsymbol{\%})\end{array}$ & $\begin{array}{c}\text { Decreasing of } \\
\text { MDA Levels in } \\
\text { Blood towards } \\
\text { Positive Control } \\
(\boldsymbol{\%})\end{array}$ \\
\hline Negative control & - & - \\
Positive control & $1.245 \pm 0.032^{\mathrm{a}}$ & 205.62 & - \\
$0.5 \mathrm{~mL} / \mathrm{rat} /$ day dose therapy & $3.806 \pm 0.053^{\mathrm{e}}$ & - & 45.30 \\
$1 \mathrm{~mL} / \mathrm{rat} /$ day dose therapy & $2.088 \pm 0.056^{\mathrm{cd}}$ & - & 47.49 \\
$1.5 \mathrm{~mL} / \mathrm{rat} /$ day dose therapy & $2.001 \pm 0.039^{\mathrm{c}}$ & - & 60.15 \\
\hline
\end{tabular}

Note: different notation indicates a extremely significant differences of influence $(p<0,01)$

The MDA level of therapy group lower than the positive control group. The effective dose that is the dose of $1.5 \mathrm{~mL} / \mathrm{rat} / \mathrm{day}$. Decreasing of MDA levels is due to antioxidants lactoferrin that contain in probiotic of Lactobacillus casei Shirota strain. Lactoferrin is one of the bioactive components that naturally present in milk. The mechanism of lactoferrin as an antioxidant is binding metal ion?

Probiotic of Lactobacillus casei Shirota strain also contain BSH (Bile salt Hydrolase). The BSH enzyme of lactic acid bacteria can deconjugate the bile salts produce the bile salt which less absorbed by the small intestine. Consequently, the body used cholesterol for resynthesized the bile salt that can reduce the cholesterol levels in blood. 


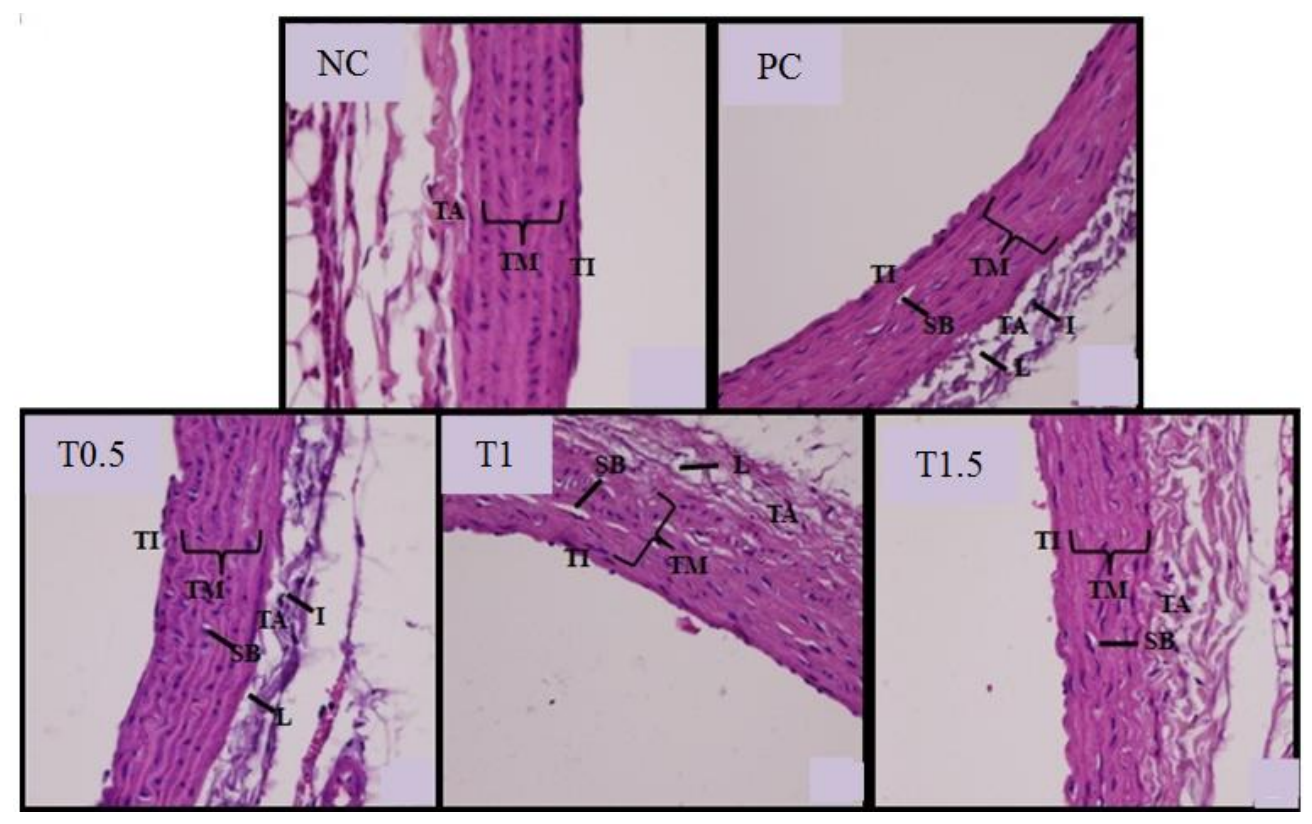

FIGURE 1. Histopathology of aortic rats with HE (magnification 400x

The cholesterol decreasing caused the decreasing of ROS levels, so that the lipid peroxidation process will decline. The declining of lipid peroxidation process will decrease the MDA levels and lead to the recondition on rat's aortic tissue.

The histopathology of aortic that negative control group showed normal structure which is characterized by the absence of fat accumulation and inflammatory cells in tunica adventitia, and also the lack of foam cells in tunica media (Fig 1). Whereas, the positive control group showed that there are fat accumulation and inflammatory cells in tunica adventitia, also foam cells formation in tunica media. The histopathology of aortic hypercholesterolemia rat involved infiltration of cells inflammatory and fat accumulation in tunica adventitia. The inflammation cells caused by ROS compound $^{8}$.

In probiotic therapy groups of Lactobacillus casei Shirota strain showed the repaired of aortic tissue which is characterized by decreasing of fat accumulation and inflammatory cells in tunica adventitia. The probiotic of Lactobacillus casei Shirota repairing of aortic histopathology. This result showed probiotic product contain Lactobacillus casei Shirota strain generate lactoferrin as an antioxidant can decrease the MDA levels and improve aortic histopathology on rat with high cholesterol diet. Dose of $1.5 \mathrm{~mL} / \mathrm{rat} / \mathrm{day}$ was the best result obtained in decreasing of MDA levels, fat accumulation, and inflammatory cells on aortic tissue. 


\section{CONCLUSION}

Therapy of probiotic Lactobacillus casei Shirota strain have potentially used as cholesterol on high cholesterol diet rats through reducing MDA levels as well as repairing aortic histopathology.

\section{REFERENCE}

1. WHO. Cardiovascular Diseases (CVDs). 2011.

2. $\quad$ M. H. Wijayakusuma. Ramuan Herbal Penurun Kolesterol. Depok: Pustaka Bunda; 2008.

3. T. Wresdiyati, M. Astawan, L. Y. Hastanti, Hewan P, Contoh P. Profil Imunohistokimia Superoksida Dismutase ( SOD ) pada Jaringan Hati Tikus dengan Kondisi Hiperkolesterolemia The Immunohistochemical Profile of Superoxide Dismutase ( SOD ) in the Liver Tissue of Hypercholesterolemic Rats. Inst Pertan Bogor. 2006;13(3):85-89.

4. M. Inoue. Protective Mechanisms Against Reactive Oxygen Species Masayasu Inoue Metabolism Of Antioxidants In The Liver 281. 2001.

5. Y. Yuniastuti. Penurun Kadar Kolesterol dengan Susu Fermentasi L. casei. Tesis, Diponegoro University, 2004.

6. R. Rachmandiar. Terhadap Kadar Kolesterol Total Dan Trigliserida Serum Pada Tikus Dislipidemia Perbedaan Pengaruh Jus Kacang Merah. 2012.

7. M. Konishi, M. Iwasa. K. Yamauchi. R. Sugimoto, N. Fujita, Y. Kobayashi, S. Watanabe, S. Teragouchi, Adachi Y KM. Lactoferrin inhibits lipid peroxidationin patient with chronic hepatitis C. 2006: 27-32.

8. D. G. Riesanti. Kadar HDL, Kadar LDL dan Gambaran Histopatologi Aorta Pada Hewan Model Tikus (Rattus norvegicus) Hiperkolesterolemia Dengan Terapi Ekstrak Air Benalu Mangga (Dendrophthoe pentandra). Brawijaya University. 2012. 